\title{
The synthesis and transformations of fused bicyclo[2.2.2]octenes
}

\author{
Jure Hren, Slovenko Polanc and Marijan Kočevar* \\ Faculty of Chemistry and Chemical Technology, University of Ljubljana, Aškerčeva 5, SI-1000 \\ Ljubljana, Slovenia \\ E-mail: marijan.kocevar@fkkt.uni-lj.si
}

Dedicated to Professor Alan R. Katritzky on the occasion of his $80^{\text {th }}$ birthday

\begin{abstract}
The synthesis and transformations of bicyclo[2.2.2] octenes with the emphasis on substituted bicyclo[2.2.2] oct-7-ene-2,3,5,6-tetracarboxylic acid derivatives bearing a substituted amino group at the bridgehead carbon atom are presented. The main topic of this review is the Diels-Alder reaction, as the most important tool for preparing compounds of this type. The transformations of bicyclo[2.2.2] oct-7-ene-2,3,5,6-tetracarboxylic acid dianhydride derivatives with nitrogen-containing nucleophiles are discussed as well as the derivatisation of the olefinic $\mathrm{C}=\mathrm{C}$ double bond.
\end{abstract}

Keywords: Bicyclo[2.2.2]octene derivatives, Diels-Alder reaction, 2H-pyran-2-ones, anhydrides, succinimides, nucleophiles, hydrogenation

\section{Table of Contents}

1. Introduction

2. The Synthesis of Various Bicyclo[2.2.2]oct-7-ene-2,3,5,6-tetracarboxylic Acid Dianhydride Derivatives

3. The Synthesis of Fused Succinimide Derivatives of Bicyclo[2.2.2]octene through a Cycloaddition Reaction

4. Transformations of Succinic Anhydride Rings Fused to a Bicyclo[2.2.2]octene Skeleton with Nucleophiles

4.1. Reactions with hydrazines and amines

4.2. The synthesis of tetraalkyl tetraesters of bicyclo[2.2.2] oct-7-ene-2,3,5,6-tetracarboxylic acid

5. Other Transformations of Bicyclo[2.2.2] oct-7-ene-2,3,5,6-tetracarboxylic Acid Derivatives

6. Transformations of the Bicyclo[2.2.2] octene $\mathrm{C}=\mathrm{C}$ Double Bond

7. Conclusions 


\section{Introduction}

Bicyclo[2.2.2] oct-7-enes (bicyclo[2.2.2]oct-2-ene when unsubstituted; structure 1, Scheme 1) represent a very interesting and synthetically challenging class of compounds that have attracted the attention of numerous organic chemists. The representatives of this class can be found in nature and their complete syntheses have also been published (for instance, eremolactone 2). ${ }^{1}$ In many cases the bicyclo[2.2.2] octene skeleton is a part of a more complex polycyclic framework, like in kopsidasine (3), a representative of the naturally occurring Kopsia alkaloids. ${ }^{2}$ It is also worth mentioning that a random study of activities revealed that mitindomide (4) possessing the bicyclo[2.2.2] octene skeleton exhibited a strong and repeatable antitumor activity in vivo. Its water-soluble and structurally symmetrical counterpart 5, which lacks the cyclobutane fragment, also shows a certain antitumor activity. ${ }^{3}$

In this account we present some of the most efficient and attractive ways of constructing the bicyclo[2.2.2] octene moiety ${ }^{4}$ as well as summarizing our recent work in the field of differently substituted bicyclo[2.2.2] oct-7-ene-2exo,3exo,5exo,6exo-tetracarboxylic acid 2,3:5,6dianhydrides $6^{5}$ with various nitrogen nucleophiles (hydrazines and amines). A subsequent transformation of the products thus obtained, including the $\mathrm{C}=\mathrm{C}$ double-bond reductions, will also be discussed.

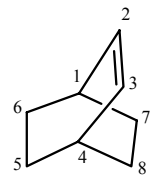

1

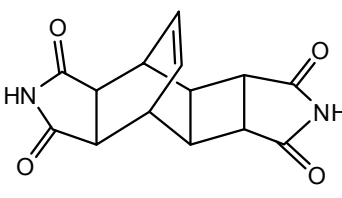

4

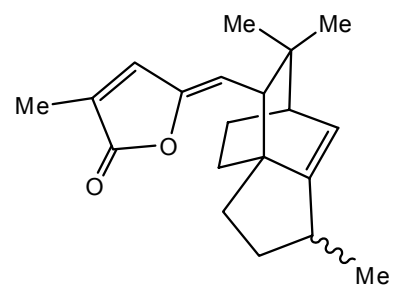

2

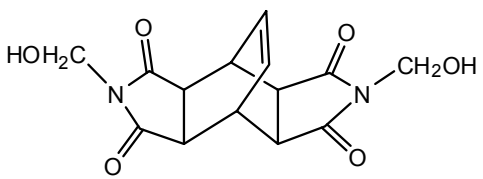

5

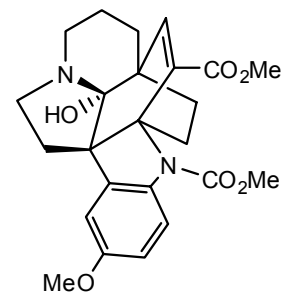

3

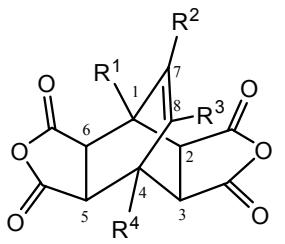

6

Scheme 1. Various bicyclo[2.2.2] octene-skeleton-containing compounds.

\section{The Synthesis of Various Bicyclo[2.2.2]oct-7-ene-2,3,5,6-tetracarboxylic Acid Dianhydride Derivatives}

There are various ways of preparing bicyclo[2.2.2] oct-7-ene-tetracarboxylic acid dianhydride derivatives 6; one of the most usual being a double Diels-Alder cycloaddition of maleic anhydride (8), acting as a dienophile onto the $2 \mathrm{H}$-pyran-2-one core 7 (Scheme 2). ${ }^{4}$ The first 
intermediate in the synthesis is a bicyclic bridged lactone 9, which is formed through the usual thermal [4+2] cycloaddition reaction. Since these reactions are usually run at high temperatures (reflux in toluene, mesitylene, xylene, tetralin, etc.), ${ }^{6}$ a spontaneous extrusion of $\mathrm{CO}_{2}$ immediately follows the cycloaddition step and another diene $\mathbf{1 0}$ is formed. The latter reacts with a second molecule of maleic anhydride (8), thus forming a double cycloadduct $\mathbf{6}$.

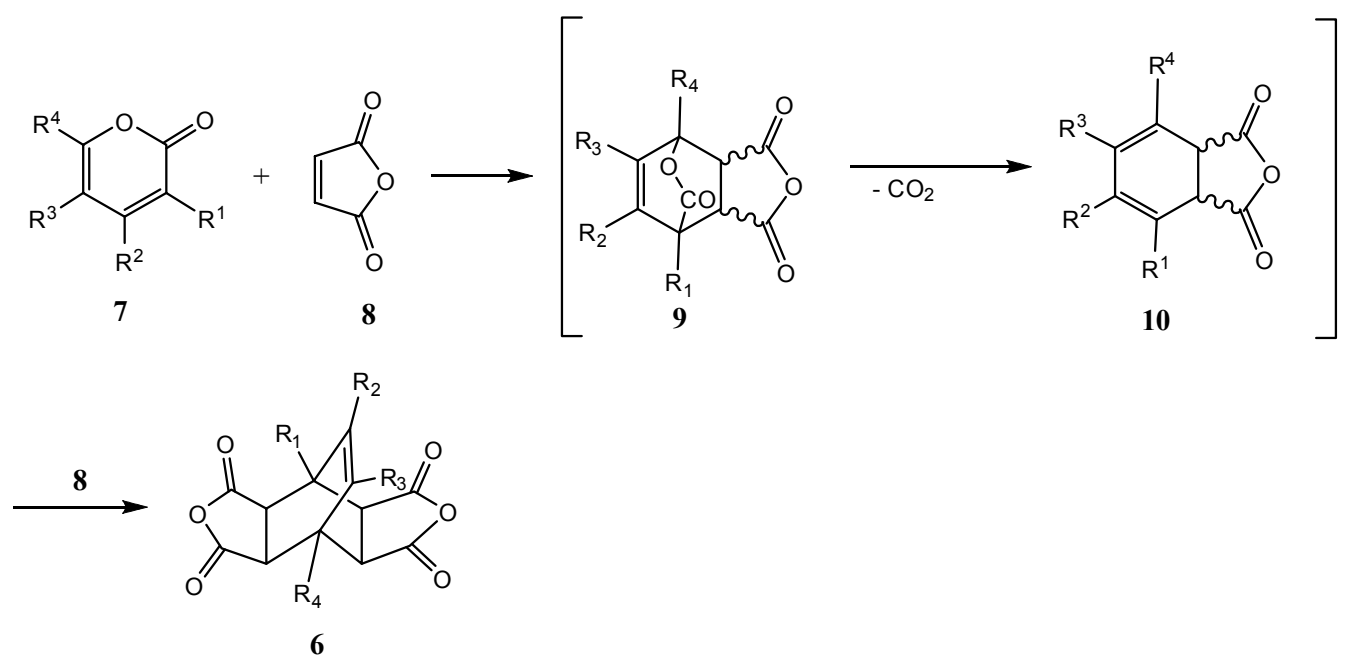

Scheme 2. Reaction of substituted $2 H$-pyran-2-one 7 with maleic anhydride 8.

Other ways of preparing this system include the Diels-Alder reaction of a substituted cyclopentadienone system, which is prepared in situ from a stable precursor (4-hydroxy-3,4diphenylcyclopent-2-enone derivative) through a dehydration reaction. ${ }^{7}$ The subsequent addition of one molecule of maleic anhydride, the extrusion of carbon monoxide and the addition of the second molecule of the maleic anhydride leads to a system of type 6. Some pathways start with an appropriately substituted thiophene derivative, which is in turn oxidized to sulphone. After the first cycloaddition step the sulfur dioxide is eliminated and thus a new diene is formed. It again reacts with another molecule of dienophile, yielding the product with a bicyclo[2.2.2] octene skeleton. ${ }^{8}$ It is also worth mentioning that the starting diene does not need to be a cyclic compound. For example, the reaction of $(1 E, 3 E)-4$-(trimethylsilyl)buta-1,3-dienyl acetate with maleic anhydride produced $6 \mathbf{6}\left(6: \mathrm{R}^{1}=\mathrm{R}^{2}=\mathrm{R}^{3}=\mathrm{R}^{4}=\mathrm{H}\right)$ in a $95 \%$ yield after one hour of heating at $100{ }^{\circ} \mathrm{C}$, and in the absence of a solvent. ${ }^{9}$ Vinylketene dithioacetal could also be used as a diene. Here, the regeneration of the diene system, which is necessary for the bicyclic product formation, is enabled through the elimination of thiomethanol. ${ }^{10}$

We reported the synthesis of a series of highly substituted double cycloadducts, bearing a protected amino substituent at the bridgehead carbon atom. These were obtained with the cycloaddition of maleic anhydride (8) onto various $2 H$-pyran-2-ones. Compounds with this pattern of substitution are extremely rare. One of them is the bridgehead-functionalized bicyclo[2.2.2] octenone 13, synthesized by Kende et al. (Scheme 3). ${ }^{11}$ 


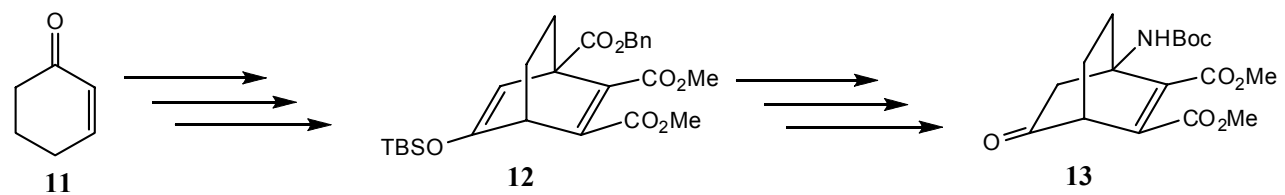

Scheme 3. Bridgehead-functionalized bicyclo[2.2.2]octenone and its precursors.

Our approach to the derivatives of the bicyclo[2.2.2] octene system involved the application of 3-benzoylamino-2 $\mathrm{H}$-pyran-2-ones $\mathbf{1 4} \mathbf{a}-\mathbf{j}^{\mathbf{1 2}}$ as dienes in the reaction with maleic anhydride $\mathbf{8}$ (Scheme 4). ${ }^{13}$ With the use of refluxing tetralin we were able to synthesize the doublecycloaddition products 15a-k in short reaction times with good-to-excellent yields (Table 1). The products are formed as crystalline precipitates; their isolation requires only filtration and rinsing with methanol.
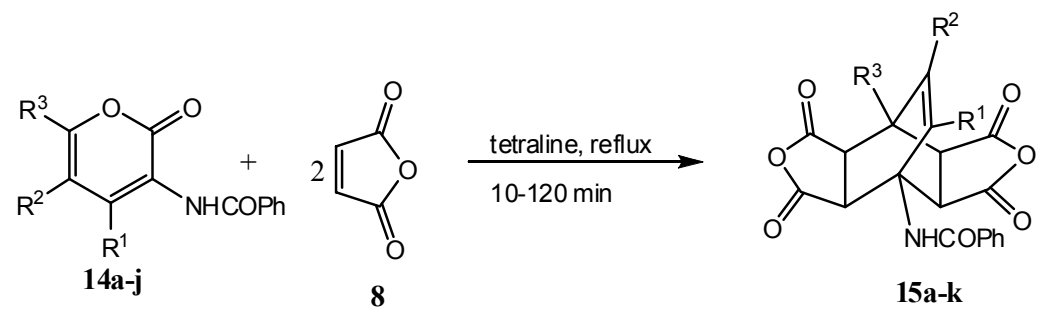

Scheme 4. Synthesis of bicyclo[2.2.2]oct-7-ene-tetracarboxylic acid dianhydrides with a benzamide substituent at the bridgehead carbon atom.

Table 1

\begin{tabular}{|c|c|c|c|c|c|c|c|}
\hline Run & Starting 14 & $\mathrm{R}^{1}$ & $\mathrm{R}^{2}$ & $\mathrm{R}^{3}$ & $\mathrm{t}(\min )$ & $\begin{array}{c}\begin{array}{c}\text { Yield } \\
(\%)\end{array} \\
\end{array}$ & $\begin{array}{c}\text { Produc } \\
\mathbf{1 5}\end{array}$ \\
\hline 1 & $14 a$ & $\mathrm{H}$ & $\mathrm{H}$ & $\mathrm{Me}$ & 15 & 64 & $15 \mathrm{a}$ \\
\hline 2 & $14 \mathrm{~b}$ & $\mathrm{H}$ & $\mathrm{H}$ & 2-thienyl & 60 & 76 & $15 \mathrm{~b}$ \\
\hline 3 & $14 \mathrm{c}$ & $\mathrm{H}$ & $\mathrm{H}$ & 2-furyl & 60 & 72 & $15 \mathrm{c}$ \\
\hline 4 & 14d & $\mathrm{H}$ & $\mathrm{H}$ & $\mathrm{Ph}$ & 120 & 76 & $15 d$ \\
\hline 5 & $14 \mathrm{e}$ & $\mathrm{H}$ & $\mathrm{COMe}$ & $\mathrm{Me}$ & 90 & 39 & $15 \mathrm{e}$ \\
\hline 6 & $14 \mathrm{f}$ & $\mathrm{H}$ & 4- $\mathrm{MeOC}_{6} \mathrm{H}_{4}$ & $\mathrm{Me}$ & 10 & 94 & $15 f$ \\
\hline 7 & $14 \mathrm{~g}$ & $\mathrm{Me}$ & $\mathrm{H}$ & $\mathrm{Ph}$ & 90 & 80 & $15 \mathrm{~g}$ \\
\hline 8 & $14 \mathrm{~h}$ & $\mathrm{Me}$ & $\mathrm{H}$ & 2-thienyl & 90 & 80 & $15 \mathrm{~h}$ \\
\hline 9 & $14 i$ & $\mathrm{H}$ & \multicolumn{2}{|c|}{$-\left(\mathrm{CH}_{2}\right)_{4^{-}}$} & 30 & 63 & $15 i$ \\
\hline 10 & $14 j$ & $\mathrm{H}$ & \multicolumn{2}{|c|}{$-\left(\mathrm{CH}_{2}\right)_{5^{-}}$} & 60 & 69 & $15 j$ \\
\hline 11 & $14 \mathrm{k}$ & $\mathrm{Me}$ & $\mathrm{H}$ & 2-furyl & 90 & 80 & $15 k$ \\
\hline
\end{tabular}


It is also worth noting that the starting compounds containing either thienyl or furyl substituents $(\mathbf{1 4 b}, \mathbf{1 4 c}, \mathbf{1 4 h}$ and $\mathbf{1 4 k})$ react specifically only with the $2 H$-pyran-2-one ring as dienophile, yielding the products $15 \mathrm{~b}, \mathbf{1 5 c}, \mathbf{1 5 h}$ and $15 \mathrm{k}$ as single isomers. The required reaction time seems to decrease if the substituents $R^{1}$ and $R^{2}$ are electron donating (for example, $R^{2}=4$ $\mathrm{MeOC}_{6} \mathrm{H}_{4}$, Run 6), which is consistent with the normal electron demand of the Diels-Alder reaction.

Based on the ${ }^{1} \mathrm{H}$ NMR spectra of the compounds $15 \mathbf{a}-\mathbf{k}$ a plane of symmetry was evident, but there was still some ambiguity. There were two possible types of products: I or II. The stereochemical configuration of the products was elucidated by an X-ray study of the compound 15e, which was shown to be of type $\mathbf{I}$, in accordance with the previous reports., 4

The formation of these products is also in accordance with the endo-kinetic control of the Diels-Alder reaction. ${ }^{5}$ There are just a few previously described examples involving maleimides as dienophiles in which unsymmetrical products were obtained under photochemical conditions. $^{14}$
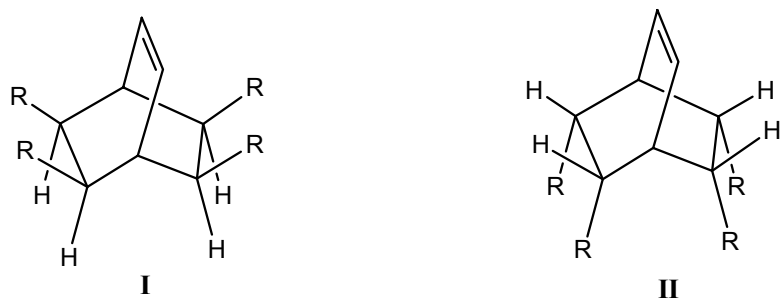

\section{The Synthesis of Fused Succinimide Derivatives of Bicyclo[2.2.2]octene through a Cycloaddition Reaction}

Bis(succinimide) derivatives of bicyclo[2.2.2] oct-7-ene can be synthesized in the same way as their dianhydride counterparts. The double cycloaddition of maleimides onto pyran-2-one derivatives leads via a several-step reaction to substituted, fused bis(succinimide) derivatives of bicyclo[2.2.2] octene. We first reported such a reaction on a fused $2 \mathrm{H}$-pyran-2-one substrate 14i (Scheme 5) with $N$-ethylmaleimide $\left(\mathbf{1 7 c}, \mathrm{R}^{4}=\mathrm{Et}\right)$, where after $8.75 \mathrm{~h}$ of refluxing in boiling decalin the corresponding 21 was isolated in a 56\% yield. In the case of derivatives $\mathbf{1 6}$ (where $\mathrm{X}=\mathrm{CO})$ after prolonged reaction times in refluxing decalin $(>20 \mathrm{~h})$ only the appropriately substituted benz[ $e$ ]indoles $\mathbf{2 0}$ were formed. To get an insight into the reaction mechanism of the latter transformation (where $\mathrm{X}=\mathrm{CO}$ ) we stopped some of the reactions after $1.5 \mathrm{~h}$ of refluxing and obtained the corresponding bicyclo[2.2.2]octene derivatives $\mathbf{2 1}$ as the major products (together with lesser amounts of benz $[e]$ indoles $\mathbf{2 0}$ and unreacted starting pyran-2-ones 16). The reaction toward 20 must therefore also include a retro Diels-Alder reaction followed by an aromatization reaction. It was also proven that the presence of $\mathrm{Rh} / \mathrm{C}$ accelerates the reaction toward the products $\mathbf{2 0} .^{15}$ 


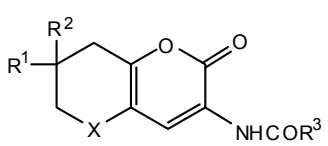

14i: $\mathrm{X}=\mathrm{CH} 2, \mathrm{R}^{1}=\mathrm{R}^{2}=\mathrm{H}$ 16: $X=C O, R^{1}=R^{2}=M e, H$
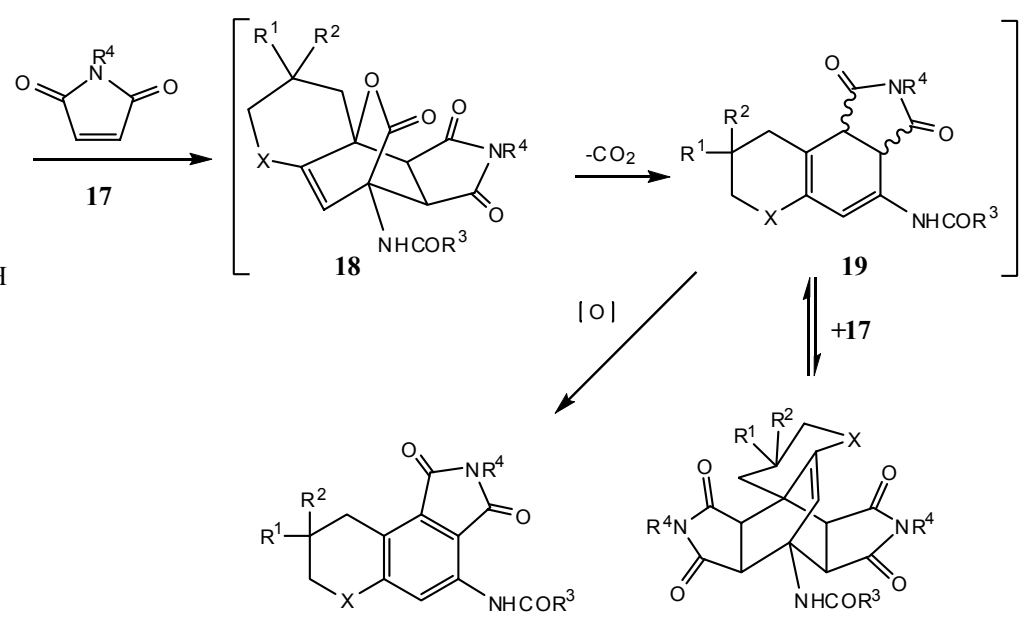

20

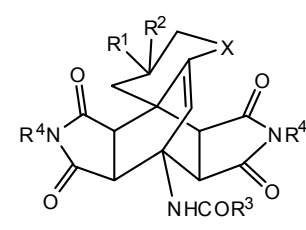

21

Scheme 5. Diels-Alder reactions of fused pyran-2-ones with maleimides.

We further expanded the library of bis(succinimide) derivatives of bicyclo[2.2.2] oct-7-enes 22 by employing differently substituted $2 \mathrm{H}$-pyran-2-ones $\mathbf{1 4}$ and several $\mathrm{N}$-alkyl substituted maleimides $\mathbf{1 7}$ as the starting materials and reacting them in water, as a solvent, and applying microwaves as the source of energy (Scheme 6, Table 2). ${ }^{16}$

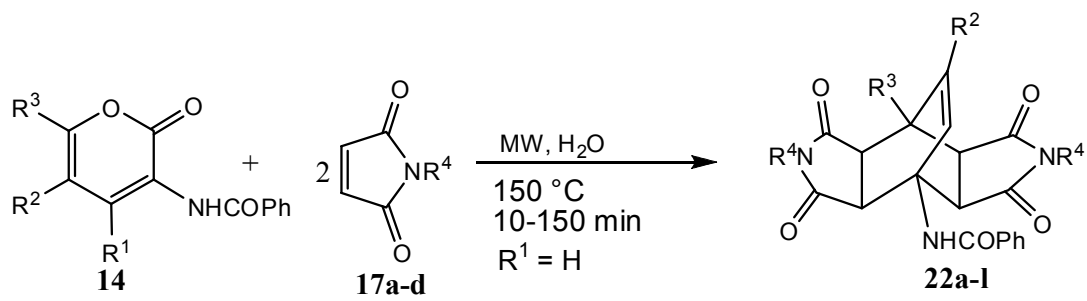

Scheme 6. Microwave-assisted synthesis of bis(succinimide) derivatives of bicyclo[2.2.2] oct-7enes 22 in water.

Despite the negligible solubility of the substrates $\mathbf{1 4}$ in water at room temperature, most of the cycloaddition reactions were complete within one hour of the irradiation with microwaves at $150{ }^{\circ} \mathrm{C}$, affording the bicyclo[2.2.2] octene derivatives in very good yields. In runs 11 and 12 we found that neat reaction conditions were beneficial for the reactions as the reaction times and the formation of side-products were reduced considerably. The use of microwaves as the energy source and water as the reaction medium seems to have a large effect on the reaction times. If the syntheses of products $22 \mathbf{d}$ and $\mathbf{2 2 h}$ (runs 4 and 8) were carried out in refluxing decalin, bp 189-191 ${ }^{\circ} \mathrm{C}$, after 90-120 $\min \mathbf{2 2 d}$ and $\mathbf{2 2 h}$ were obtained in 81 and 76\% yields, respectively. This was good evidence that the use of water as the reaction medium and microwaves as a source of heating are beneficial in comparison with thermal reactions in decalin. 
Table 2

\begin{tabular}{|c|c|c|c|c|c|c|c|c|}
\hline Run & $\begin{array}{c}\text { Starting } \\
\mathbf{1 4} \\
\left(\mathrm{R}^{1}=\mathrm{H}\right)\end{array}$ & $\mathrm{R}^{2}$ & $\mathrm{R}^{3}$ & $\mathrm{R}^{4}$ & $\begin{array}{c}\text { Starting } \\
\mathbf{1 7}\end{array}$ & $\mathrm{t}(\mathrm{min})^{a}$ & $\begin{array}{l}\text { Yield } \\
(\%)^{b}\end{array}$ & $\begin{array}{c}\text { Prod. } \\
22\end{array}$ \\
\hline 1 & $14 b$ & $\mathrm{H}$ & 2-thenyl & Et & $17 \mathrm{c}$ & 150 & 96 & $22 a$ \\
\hline 2 & $14 \mathrm{c}$ & $\mathrm{H}$ & 2-furyl & $\mathrm{Ph}$ & $17 d$ & 90 & 99 & $22 b$ \\
\hline 3 & $14 \mathrm{e}$ & $\mathrm{COMe}$ & $\mathrm{Me}$ & $\mathrm{H}$ & $17 \mathbf{a}$ & 20 & 82 & $22 \mathrm{c}$ \\
\hline 4 & $14 \mathrm{e}$ & $\mathrm{COMe}$ & $\mathrm{Me}$ & $\mathrm{Me}$ & $17 b$ & 30 & 87 & 22d \\
\hline 5 & $14 \mathrm{e}$ & $\mathrm{COMe}$ & $\mathrm{Me}$ & $\mathrm{Et}$ & $17 \mathrm{c}$ & 30 & 92 & $22 \mathrm{e}$ \\
\hline 6 & $14 \mathrm{e}$ & $\mathrm{COMe}$ & $\mathrm{Me}$ & $\mathrm{Ph}$ & 17d & 30 & 94 & $22 f$ \\
\hline 7 & $14 f$ & $4-\mathrm{MeOC}_{6} \mathrm{H}_{4}$ & $\mathrm{Me}$ & $\mathrm{Ph}$ & 17d & 10 & 93 & $22 \mathrm{~g}$ \\
\hline 8 & 141 & $\mathrm{CO}_{2} \mathrm{Et}$ & $\mathrm{Me}$ & $\mathrm{Me}$ & $17 b$ & 45 & 86 & $22 \mathrm{~h}$ \\
\hline 9 & 141 & $\mathrm{CO}_{2} \mathrm{Et}$ & $\mathrm{Me}$ & Et & $17 \mathrm{c}$ & 45 & 87 & $22 \mathrm{i}$ \\
\hline 10 & 141 & $\mathrm{CO}_{2} \mathrm{Et}$ & $\mathrm{Me}$ & $\mathrm{Ph}$ & 17d & 60 & 91 & $22 j$ \\
\hline 11 & $14 m$ & $\mathrm{CO}_{2} \mathrm{Me}$ & $\mathrm{CH}_{2} \mathrm{CO}_{2} \mathrm{Me}$ & Et & $17 \mathrm{c}$ & $30^{c}$ & $82^{d}$ & $22 k$ \\
\hline 12 & $14 \mathrm{~m}$ & $\mathrm{CO}_{2} \mathrm{Me}$ & $\mathrm{CH}_{2} \mathrm{CO}_{2} \mathrm{Me}$ & $\mathrm{Ph}$ & $17 d$ & $30^{c}$ & $81^{d}$ & 221 \\
\hline
\end{tabular}

${ }^{\mathrm{a}}$ Microwave irradiation at $150{ }^{\circ} \mathrm{C}$ in a pressurized tube. ${ }^{\mathrm{b}}$ Yield of isolated products. ${ }^{\mathrm{c}}$ Neat reaction. ${ }^{\mathrm{d}}$ Yield after crystallization from $\mathrm{EtOH}$.

We attempted to expand our methodology toward the library of fused succinimide derivatives of the bicyclo[2.2.2] octene system by further varying the substitution pattern on the starting $2 \mathrm{H}$ pyran-2-ones 14 as well as the reaction conditions (Scheme 7, Table 3). ${ }^{17}$ Here, we have applied neat reaction conditions in the presence of a minor amount of a liquid additive (butan-1-ol) and microwave heating, a method which was previously shown to be beneficial in terms of the degree of conversion and the reaction time. ${ }^{18} \mathrm{We}$ found that this was also the case in the double cycloaddition reaction of maleimides. In other words, the reactions in the presence of small amounts of butan-1-ol took place with higher conversions than the same reactions in the absence of any additive or in butan-1-ol as a solvent. The role of the liquid additive was to rinse the sublimed maleimides from the colder, upper parts of the closed microwave reaction vessel to the lower parts of the same vessel, where the reaction with nonvolatile $2 \mathrm{H}$-pyran-2-ones takes place. 


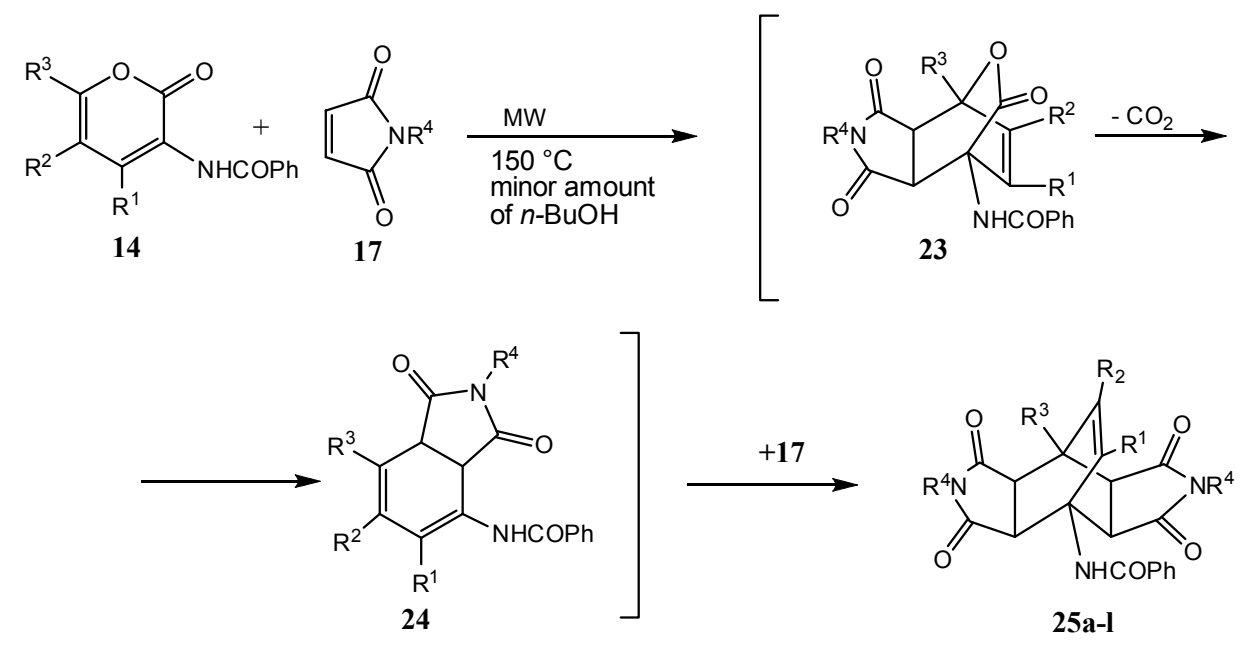

Scheme 7. Synthesis of bis(succinimide) derivatives of bicyclo[2.2.2]oct-7-enes 25 under microwave conditions with the assistance of a minor amount of $n-\mathrm{BuOH}$.

Table 3

\begin{tabular}{cccccccccc}
\hline Run & $\begin{array}{c}\text { Starti } \\
\text { ng 14 }\end{array}$ & $\mathrm{R}^{1}$ & $\mathrm{R}^{2}$ & $\mathrm{R}^{3}$ & $\begin{array}{c}\text { Starting } \\
\mathbf{1 7}\end{array}$ & $\mathrm{R}^{4}$ & $\begin{array}{c}\mathrm{t} \\
(\mathrm{min})^{a}\end{array}$ & $\begin{array}{c}\text { Yield } \\
(\mathbf{\%})^{b}\end{array}$ & $\begin{array}{c}\text { Prod. } \\
\mathbf{2 5}\end{array}$ \\
\hline 1 & $\mathbf{1 4 a}$ & $\mathrm{H}$ & $\mathrm{H}$ & $\mathrm{Me}$ & $\mathbf{1 7 c}$ & $\mathrm{Et}$ & 15 & 93 & $\mathbf{2 5 a}$ \\
2 & $\mathbf{1 4 b}$ & $\mathrm{H}$ & $\mathrm{H}$ & 2-thienyl & $\mathbf{1 7 d}$ & $\mathrm{Ph}$ & 40 & 98 & $\mathbf{2 5 b}$ \\
3 & $\mathbf{1 4 c}$ & $\mathrm{H}$ & $\mathrm{H}$ & 2 -furyl & $\mathbf{1 7 c}$ & $\mathrm{Et}$ & 45 & 95 & $\mathbf{2 5 c}$ \\
4 & $\mathbf{1 4 c}$ & $\mathrm{H}$ & $\mathrm{H}$ & 2 -furyl & $\mathbf{1 7 b}$ & $\mathrm{Me}$ & 45 & 93 & $\mathbf{2 5 d}$ \\
5 & $\mathbf{1 4 d}$ & $\mathrm{H}$ & $\mathrm{H}$ & $\mathrm{Ph}$ & $\mathbf{1 7 c}$ & $\mathrm{Et}$ & 45 & 85 & $\mathbf{2 5 e}$ \\
6 & $\mathbf{1 4 d}$ & $\mathrm{H}$ & $\mathrm{H}$ & $\mathrm{Ph}$ & $\mathbf{1 7 d}$ & $\mathrm{Ph}$ & 25 & 94 & $\mathbf{2 5 f}$ \\
7 & $\mathbf{1 4 f}$ & $\mathrm{H}$ & $4-\mathrm{MeOC} \mathrm{H}_{4}$ & $\mathrm{Me}$ & $\mathbf{1 7 c}$ & $\mathrm{Et}$ & 15 & 86 & $\mathbf{2 5 g}$ \\
8 & $\mathbf{1 4 g}$ & $\mathrm{Me}$ & $\mathrm{H}$ & $\mathrm{Ph}$ & $\mathbf{1 7 c}$ & $\mathrm{Et}$ & $90^{\mathrm{c}}$ & 88 & $\mathbf{2 5 h}$ \\
9 & $\mathbf{1 4 g}$ & $\mathrm{Me}$ & $\mathrm{H}$ & $\mathrm{Ph}$ & $\mathbf{1 7 d}$ & $\mathrm{Ph}$ & 50 & 97 & $\mathbf{2 5 i}$ \\
10 & $\mathbf{1 4 h}$ & $\mathrm{Me}$ & $\mathrm{H}$ & $2-t h i e n y l$ & $\mathbf{1 7 c}$ & $\mathrm{Et}$ & 60 & 96 & $\mathbf{2 5 j}$ \\
11 & $\mathbf{1 4 h}$ & $\mathrm{Me}$ & $\mathrm{H}$ & $2-t h i e n y l$ & $\mathbf{1 7 d}$ & $\mathrm{Ph}$ & 90 & 98 & $\mathbf{2 5 k}$ \\
12 & $\mathbf{1 4 n}$ & $\mathrm{H}$ & $3,4-(\mathrm{MeO})_{2} \mathrm{C}_{6} \mathrm{H}_{4}$ & $\mathrm{Me}$ & $\mathbf{1 7 c}$ & $\mathrm{Et}$ & 10 & 92 & $\mathbf{2 5 l}$ \\
\hline
\end{tabular}

${ }^{\mathrm{a}}$ Microwave irradiation at $150{ }^{\circ} \mathrm{C}$ in a pressurized tube with the addition of $100 \mathrm{mg}$ butan-1-ol. ${ }^{\mathrm{b}}$ Yield of isolated products. ${ }^{\mathrm{c}}$ Temperature was set to $160^{\circ} \mathrm{C}$.

It is also worth mentioning that this method does not require a large excess of maleimide (only 5\% excess is needed) and, due to an easy work-up (filtration and washing), it is very appropriate for the synthesis of a large number of new compounds. We have thus synthesized a library of compounds with the use of microwaves and minimal solvent requirements (water and a small amount of additive) by a simple and eco-friendly green approach. 


\section{Transformations of Succinic Anhydride Rings Fused to a Bicyclo[2.2.2]- octene Skeleton with Nucleophiles}

\subsection{Reactions with hydrazines and amines}

It is well known that anhydrides react with amines and hydrazines, producing the corresponding amides and imides. ${ }^{19}$ Before our investigation in this field started, to our knowledge there had only been one report on the utilization of the fused bicyclo[2.2.2] octene system (but not containing an amino group at the bridgehead) in a reaction with hydrazine hydrate and phenylhydrazine in an ethanolic solution. ${ }^{20}$ Only two products were prepared in this investigation and no details about the reaction times were given. Therefore, we decided to investigate the reactivity of the anhydride moieties of bicyclo[2.2.2]oct-7-ene-2exo,3exo,5exo,6exotetracarboxylic acid 2,3:5,6-dianhydrides 15 toward various hydrazines and amines. Our idea was to perfom this reaction in green conditions, i.e., in an aqueous mixture, and to apply microwaves as the source of heating. With the starting material $\mathbf{1 5}$ readily available from the previously mentioned double cycloadditions of maleic anhydride with $2 H$-pyran-2-ones, it proved to be an effective way of synthesizing a library of differently substituted, fused $\mathrm{N}$ aminosuccinimide derivatives of bicyclo[2.2.2] octene 27 (Scheme 8, Table 4). ${ }^{21}$

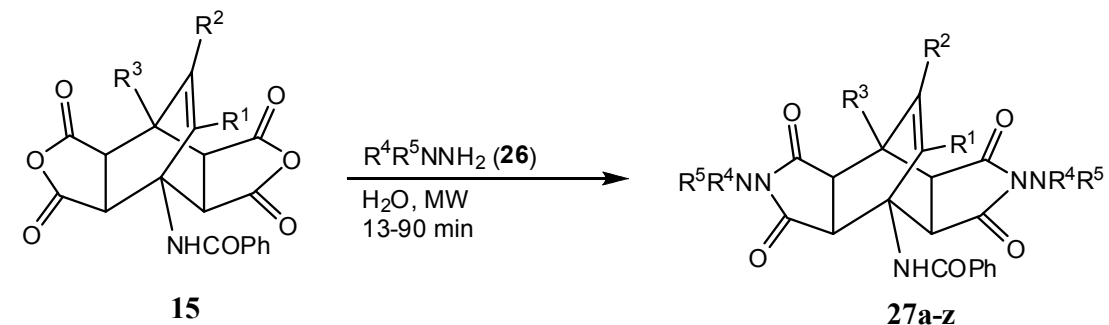

Scheme 8. Synthesis of differently substituted $N$-aminosuccinimide derivatives 27 of bicyclo[2.2.2] octene from $\mathbf{1 5}$ and hydrazines $\mathbf{2 6}$ with water as the solvent and microwaves as the source of energy.

The reaction runs well in most cases, even with a small excess of hydrazine (1.2 eq.). In the case when we applied this transformation to the adduct 15e, the reaction of the carbonyl group proceeded as well (Scheme 9, Table 5). This reaction enabled us to obtain $N$-aminosuccinimide products 28 containing an additional hydrazono group. ${ }^{21 \mathrm{~b}}$ 
Table 4

\begin{tabular}{|c|c|c|c|c|c|c|c|c|c|}
\hline \multirow{2}{*}{ Run } & \multirow{2}{*}{15} & \multirow{2}{*}{$\mathrm{R}^{1}$} & \multirow{2}{*}{$\mathrm{R}^{2}$} & \multirow{2}{*}{$\mathrm{R}^{3}$} & \multicolumn{2}{|c|}{26} & \multirow{2}{*}{$\begin{array}{c}\mathrm{t} \\
(\mathrm{min})\end{array}$} & \multirow{2}{*}{$\begin{array}{c}\text { Yield }^{\mathrm{d}} \\
(\%)\end{array}$} & \multirow{2}{*}{ Prod } \\
\hline & & & & & $\mathrm{R}^{4}$ & $\mathrm{R}^{5}$ & & & \\
\hline 1 & $15 a$ & $\mathrm{H}$ & $\mathrm{H}$ & $\mathrm{Me}$ & $\mathrm{H}$ & $\mathrm{H}$ & $50^{\mathrm{a}}$ & 94 & $27 a$ \\
\hline 2 & $15 a$ & $\mathrm{H}$ & $\mathrm{H}$ & $\mathrm{Me}$ & $\mathrm{H}$ & $\mathrm{Me}$ & $13^{\mathrm{a}}$ & 94 & $27 b$ \\
\hline 3 & $15 b$ & $\mathrm{H}$ & $\mathrm{H}$ & 2-thienyl & $\mathrm{H}$ & $\mathrm{H}$ & $45^{\mathrm{b}}$ & 88 & $27 c$ \\
\hline 4 & $15 \mathrm{c}$ & $\mathrm{H}$ & $\mathrm{H}$ & 2-furyl & $\mathrm{H}$ & $\mathrm{Me}$ & $20^{\mathrm{b}}$ & 93 & $27 d$ \\
\hline 5 & $15 \mathrm{c}$ & $\mathrm{H}$ & $\mathrm{H}$ & 2-furyl & $\mathrm{H}$ & $\mathrm{H}$ & $40^{\mathrm{b}}$ & 83 & $27 \mathrm{e}$ \\
\hline 6 & $15 \mathrm{c}$ & $\mathrm{H}$ & $\mathrm{H}$ & 2-furyl & $\mathrm{H}$ & $4-\mathrm{BrC}_{6} \mathrm{H}_{4}$ & $75^{\mathrm{c}}$ & 93 & $27 f$ \\
\hline 7 & $15 \mathrm{c}$ & $\mathrm{H}$ & $\mathrm{H}$ & 2-furyl & $\mathrm{H}$ & $4-\mathrm{FC}_{6} \mathrm{H}_{4}$ & $90^{\mathrm{c}}$ & 95 & $27 \mathrm{~g}$ \\
\hline 8 & 15d & $\mathrm{H}$ & $\mathrm{H}$ & $\mathrm{Ph}$ & $\mathrm{H}$ & $\mathrm{Me}$ & $30^{\mathrm{b}}$ & 94 & $27 \mathrm{~h}$ \\
\hline 9 & $15 d$ & $\mathrm{H}$ & $\mathrm{H}$ & $\mathrm{Ph}$ & $\mathrm{H}$ & $\mathrm{Ph}$ & $45^{\mathrm{c}}$ & 98 & $27 \mathbf{i}$ \\
\hline 10 & $15 f$ & $\mathrm{H}$ & $4-\mathrm{MeOC}_{6} \mathrm{H}_{4}$ & $\mathrm{Me}$ & $\mathrm{H}$ & $\mathrm{H}$ & $60^{\mathrm{a}}$ & 94 & $27 \mathbf{j}$ \\
\hline 11 & $15 f$ & $\mathrm{H}$ & $4-\mathrm{MeOC}_{6} \mathrm{H}_{4}$ & $\mathrm{Me}$ & $\mathrm{H}$ & $\mathrm{Me}$ & $90^{\mathrm{b}}$ & 95 & $27 k$ \\
\hline 12 & $15 f$ & $\mathrm{H}$ & $4-\mathrm{MeOC}_{6} \mathrm{H}_{4}$ & $\mathrm{Me}$ & $\mathrm{H}$ & $\mathrm{Ph}$ & $75^{c}$ & 96 & 271 \\
\hline 13 & $15 \mathrm{~g}$ & $\mathrm{Me}$ & $\mathrm{H}$ & $\mathrm{Ph}$ & $\mathrm{H}$ & $\mathrm{H}$ & $30^{\mathrm{b}}$ & 87 & $27 m$ \\
\hline 14 & $15 \mathrm{~g}$ & $\mathrm{Me}$ & $\mathrm{H}$ & $\mathrm{Ph}$ & $\mathrm{H}$ & $\mathrm{Ph}$ & $75^{c}$ & 97 & $27 n$ \\
\hline 15 & $15 \mathrm{~g}$ & $\mathrm{Me}$ & $\mathrm{H}$ & $\mathrm{Ph}$ & $\mathrm{H}$ & 2-pyridyl & $90^{\mathrm{c}}$ & 86 & 270 \\
\hline 16 & $15 h$ & $\mathrm{Me}$ & $\mathrm{H}$ & 2-thienyl & $\mathrm{H}$ & $\mathrm{H}$ & $55^{\mathrm{b}}$ & 86 & $27 p$ \\
\hline 17 & $15 \mathrm{~h}$ & $\mathrm{Me}$ & $\mathrm{H}$ & 2-thienyl & $\mathrm{H}$ & $\mathrm{Me}$ & $30^{\mathrm{b}}$ & 92 & $27 q$ \\
\hline 18 & $15 \mathbf{i}$ & $\mathrm{H}$ & \multicolumn{2}{|c|}{$-\left(\mathrm{CH}_{2}\right)_{4^{-}}$} & $\mathrm{H}$ & $\mathrm{H}$ & 45 & 91 & $27 r$ \\
\hline 19 & $15 \mathbf{i}$ & $\mathrm{H}$ & \multicolumn{2}{|c|}{$-\left(\mathrm{CH}_{2}\right)_{4-}$} & $\mathrm{H}$ & $\mathrm{Me}$ & $40^{\mathrm{b}}$ & 80 & $27 s$ \\
\hline 20 & $15 \mathbf{i}$ & $\mathrm{H}$ & \multicolumn{2}{|c|}{$-\left(\mathrm{CH}_{2}\right)_{4}^{-}$} & $\mathrm{H}$ & $\mathrm{Ph}$ & $45^{\mathrm{b}}$ & 91 & $27 t$ \\
\hline 21 & $\mathbf{1 5 j}$ & $\mathrm{H}$ & \multicolumn{2}{|c|}{$-\left(\mathrm{CH}_{2}\right)_{5^{-}}$} & $\mathrm{H}$ & $\mathrm{Me}$ & $30^{\mathrm{b}}$ & 84 & $27 u$ \\
\hline 22 & $15 k$ & $\mathrm{Me}$ & $\mathrm{H}$ & 2-furyl & $\mathrm{H}$ & $\mathrm{H}$ & $50^{\mathrm{a}}$ & 92 & $27 v$ \\
\hline 23 & $15 \mathrm{k}$ & $\mathrm{Me}$ & $\mathrm{H}$ & 2-furyl & $\mathrm{H}$ & $\mathrm{Me}$ & $20^{\mathrm{b}}$ & 92 & $27 w$ \\
\hline 24 & $15 k$ & $\mathrm{Me}$ & $\mathrm{H}$ & 2-furyl & $\mathrm{H}$ & 2-pyridyl & $80^{\mathrm{c}}$ & 83 & $27 x$ \\
\hline 25 & $15 k$ & $\mathrm{Me}$ & $\mathrm{H}$ & 2-furyl & $\mathrm{H}$ & $\mathrm{Ph}$ & $75^{\mathrm{c}}$ & 92 & $27 y$ \\
\hline 26 & $15 k$ & $\mathrm{Me}$ & $\mathrm{H}$ & 2-furyl & $\mathrm{Me}$ & $\mathrm{Me}$ & $70^{\mathrm{c}}$ & 80 & $27 z$ \\
\hline
\end{tabular}

${ }^{\mathrm{a}}$ Microwave irradiation at $100{ }^{\circ} \mathrm{C}$. ${ }^{\mathrm{b}}$ Microwave irradiation at $150{ }^{\circ} \mathrm{C}$. ${ }^{\mathrm{c}}$ Microwave irradiation at $160{ }^{\circ} \mathrm{C} .{ }^{\mathrm{d}}$ Yields of isolated products are given. 


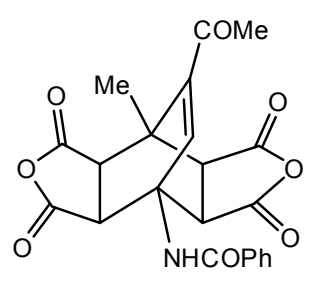

$15 \mathrm{e}$

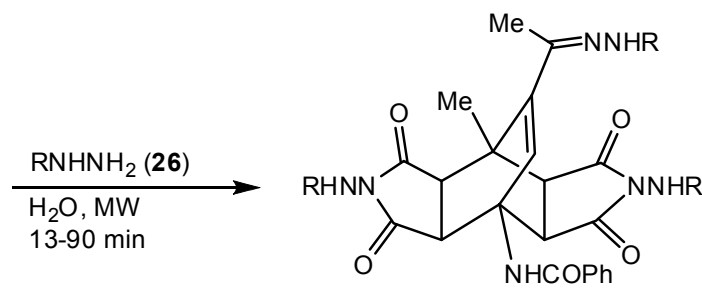

28a-c

Scheme 9. Reaction of $\mathbf{1 5 e}$ with various hydrazines to the corresponding hydrazones.

Table 5

\begin{tabular}{ccccc}
\hline Starting 26 & $\mathrm{T}\left({ }^{\circ} \mathrm{C}\right)$ & $\mathrm{t}(\mathrm{min})$ & Yield $^{\mathrm{a}},(\%)$ & Product \\
$\mathrm{R}$ & & & & \\
\hline $\mathrm{H}$ & 150 & 60 & 87 & $\mathbf{2 8 a}$ \\
$2-\mathrm{Py}$ & 160 & 75 & 95 & $\mathbf{2 8 b}$ \\
$4-\mathrm{BrC}_{6} \mathrm{H}_{4}$ & 135 & 45 & 96 & $\mathbf{2 8 c}$ \\
\hline
\end{tabular}

${ }^{\mathrm{a}}$ Yields of isolated products are given.

When we analyzed ( ${ }^{1} \mathrm{H}$ NMR) a non-completed reaction of $15 \mathbf{e}$ with hydrazine hydrate we found that the reaction mixture consisted of unreacted 15e and the product 28a, suggesting that the condensation runs simultaneously at all three reactive centers. Therefore, we have shown that this reaction, under the applied conditions, could not be undertaken in a chemoselective way.

We also wondered if the above-mentioned transformations would proceed with amines. When checking the literature we found that some reactions with representatives of these systems and amines occurred when using refluxing DMF as a solvent ${ }^{22}$ or by heating an aqueous solution for a long reaction time ${ }^{23}$ (Scheme 10).
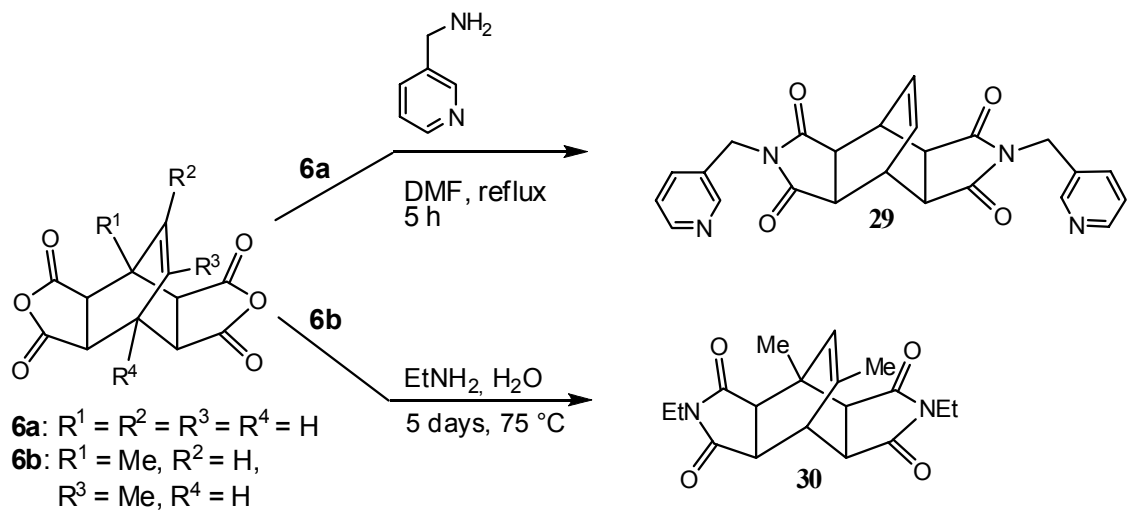

Scheme 10. Reactions of derivatives 6 with amines under various conditions. 
As amines are less nucleophilic than hydrazines, we expected that the transformations would run less smoothly than with hydrazines; however, we found that the transformation of starting $\mathbf{1 5}$ with a series of amines toward new bis(succinimide) derivatives of bicyclo[2.2.2] octene runs under similar conditions as with hydrazines, yielding products $\mathbf{2 5 m - q}$ (Scheme 11, Table 6).

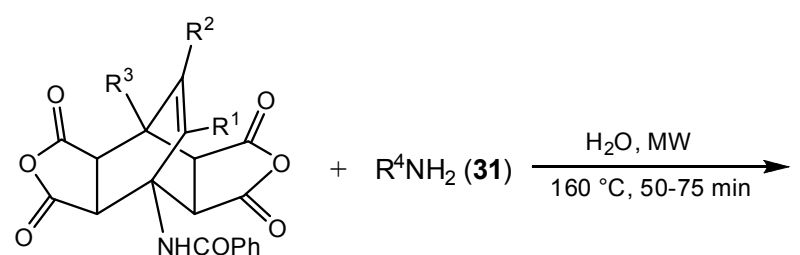

15

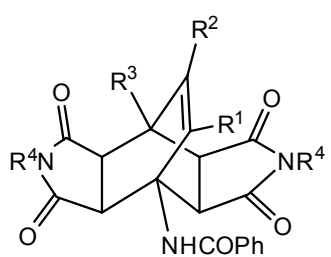

25m-q

Scheme 11. Microwave-assisted transformation of $\mathbf{1 5}$ with amines under aqueous conditions.

Table 6

\begin{tabular}{ccccccccc}
\hline Run & $\begin{array}{c}\text { Starting } \\
\mathbf{1 5}\end{array}$ & $\mathrm{R}^{1}$ & $\mathrm{R}^{2}$ & $\mathrm{R}^{3}$ & $\mathrm{R}^{4}$ & $\mathrm{t}(\mathrm{min})$ & $\begin{array}{c}\text { Yield } \\
(\%)\end{array}$ & Prod. \\
\hline 1 & $\mathbf{1 5 c}$ & $\mathrm{H}$ & $\mathrm{H}$ & 2-furyl & 3-pyridylmethyl & 50 & 99 & $\mathbf{2 5 m}$ \\
2 & $\mathbf{1 5 d}$ & $\mathrm{H}$ & $\mathrm{H}$ & $\mathrm{Ph}$ & $\mathrm{Bn}$ & 75 & 97 & $\mathbf{2 5 n}$ \\
3 & $\mathbf{1 5 f}$ & $\mathrm{H}$ & $4-\mathrm{MeOC}_{6} \mathrm{H}_{4}$ & $\mathrm{Me}$ & 3-pyridylmethyl & 50 & 93 & $\mathbf{2 5 0}$ \\
4 & $\mathbf{1 5 f}$ & $\mathrm{H}$ & $4-\mathrm{MeOC}_{6} \mathrm{H}_{4}$ & $\mathrm{Me}$ & $n$-Bu & 75 & 87 & $\mathbf{2 5 p}$ \\
5 & $\mathbf{1 5 g}$ & $\mathrm{Me}$ & $\mathrm{H}$ & $\mathrm{Ph}$ & 3-pyridylmethyl & 50 & 85 & $\mathbf{2 5 q}$ \\
\hline
\end{tabular}

${ }^{\mathrm{a}}$ Yield of isolated product.

We were also wondering how the acetyl derivative 15e would react with amines under aqueous conditions. We thought about a possible chemoselective transformation of the additional acetyl group (the reactivity of keto versus anhydride functionality). When amines react with aldehydes or ketones imines are formed; they are known, on the other hand, to hydrolyze in the presence of water and at high temperatures back to oxo derivatives. Therefore, we applied aqueous reaction conditions and microwave heating to reactions of $\mathbf{1 5 e}$ with various amines (Scheme 12, Table 7). We found that substrate 15e reacts with amines under aqueous conditions in a different way than with hydrazines. With hydrazines, hydrazones $\mathbf{2 8}$ were formed (see Scheme 9), but with amines the reaction in water does not proceed on the keto group; both anhydride moieties react, producing 32 in high yields. On the other hand, we found that carrying out the same reaction in neat conditions in the presence of a minor amount of toluene, as an additive, with only 4 eq. of aniline derivative, enables the formation of imines $\mathbf{3 3}$ under green conditions. $^{24}$ 

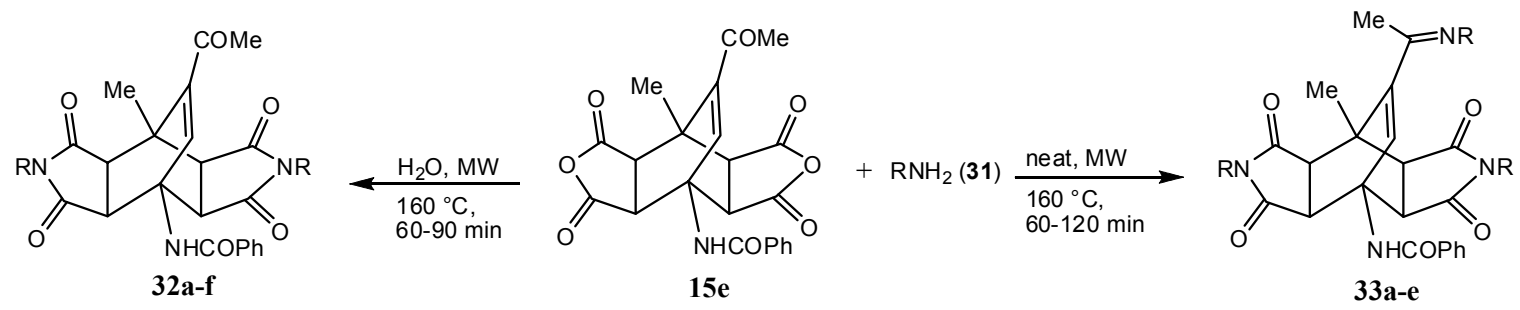

Scheme 12. Chemoselective transformations of substrate 15e under aqueous or neat reaction conditions.

Table 7

\begin{tabular}{ccccccccc}
\hline Entry & $\begin{array}{c}\text { Starting } \\
\text { 31 }\end{array}$ & $\mathrm{R}$ & $\begin{array}{c}\mathrm{t} \\
(\mathrm{min})\end{array}$ & $\begin{array}{c}\text { Aqueous } \\
\text { prod. 32 }\end{array}$ & $\begin{array}{c}\text { Yield } \\
(\%)^{\mathrm{a}}\end{array}$ & $\begin{array}{c}\mathrm{t} \\
(\mathrm{min})\end{array}$ & $\begin{array}{c}\text { Neat } \\
\text { prod. 33 }\end{array}$ & $\begin{array}{c}\text { Yield } \\
(\%)^{\mathrm{a}}\end{array}$ \\
\hline 1 & $\mathbf{3 1 a}$ & $\mathrm{Ph}$ & 60 & $\mathbf{3 2 a}$ & 90 & 60 & $\mathbf{3 3 a}$ & 75 \\
2 & $\mathbf{3 1 b}$ & $3-\mathrm{MeC}_{6} \mathrm{H}_{4}$ & 60 & $\mathbf{3 2 b}$ & 90 & 60 & $\mathbf{3 3 b}$ & 70 \\
3 & 31c & $4-\mathrm{ClC}_{6} \mathrm{H}_{4}$ & 75 & $\mathbf{3 2 c}$ & $81^{\mathrm{b}}$ & 75 & $\mathbf{3 3 c}$ & 78 \\
4 & $\mathbf{3 1 d}$ & $3,4-\mathrm{Cl}_{2} \mathrm{C}_{6} \mathrm{H}_{3}$ & 75 & $\mathbf{3 2 d}$ & $80^{\mathrm{b}}$ & 120 & $\mathbf{3 3 d}$ & 72 \\
5 & $\mathbf{3 1 e}$ & $3-\mathrm{FC}_{6} \mathrm{H}_{4}$ & 90 & $\mathbf{3 2 e}$ & $81^{\mathrm{b}}$ & 120 & 33e & 71 \\
6 & 31f & $3-$-pyridylmethyl & 60 & $\mathbf{3 2 f}$ & 90 & - & - & - \\
\hline
\end{tabular}

${ }^{a}$ Yield of isolated product. ${ }^{b}$ After crystallization $\left(\mathrm{MeOH}-\mathrm{H}_{2} \mathrm{O}\right)$.

Optimization studies on the reaction of 15e with 4-chloroaniline 31c showed that toluene is a necessary additive. Without it, no suitable condition to finish the reaction could be found. However, the amount of toluene proved to be very important. The optimal quantity was shown to be around $100 \mathrm{mg} / 0.5 \mathrm{mmol}$ of $\mathbf{1 5 e}$ in a $10-\mathrm{mL}$ reaction tube. It seems that with such small amounts of toluene the water eliminated during the reaction is evaporated and deposited on the uppermost, coldest parts of the reaction vessel. Only 4-chloroaniline, with a higher boiling point than water, is rinsed back by the toluene to the lower parts of the vessel where the reaction takes place. The formation of 32c becomes significant with larger amounts of toluene, as too much additive also rinses the water back into the reaction mixture. Running the reaction using two-fold amounts was complete under identical conditions as on the 0.5 -mmol scale. However, quadrupling the quantity of the reactants and running the reaction in a classical $10-\mathrm{mL}$ sealed tube proved to be impossible. It resulted in unusual temperature profiles. Therefore, we decided to carry out this experiment in a larger, closed reaction vessel (a heavy-wall Ace pressure tube, $38 \mathrm{~mL}$, Aldrich) and using the CEM Discover "open vessel" mode protocol. Again, the reaction was finished in 75 minutes and we isolated $\mathbf{3 3 c}$ as the sole product in an $83 \%$ yield.

The reactions proceeded with good yields and with reasonable reaction times. The imines $\mathbf{3 3}$ can be formed with aromatic (conjugated) amines only. An attempt to use nonconjugated amines (for instance, 31f) under neat reaction conditions with the substrate 15e to obtain a product similar to $\mathbf{3 3}$ was not successful. This was confirmed by the mass spectrum of the crude reaction 
mixture; an analysis using the ${ }^{1} \mathrm{H}$ NMR spectra was not possible, because of the large number of overlapping signals. The fact that imine-type products $\mathbf{3 3}$ were not formed could be attributed to the lower stability of the imine moiety when an aliphatic residue is bound to the imine nitrogen. It is also worth mentioning that the imine-type products are formed, presumably only as anti isomers, as their ${ }^{1} \mathrm{H}$ NMR spectra show only one set of signals. We presumed the anti orientation because such an isomer would be less sterically crowded, and with the aromatic and sterically demanding bicyclo[2.2.2] octene groups further apart.

Both sets of reaction conditions (aqueous and neat) complement each other nicely and products 32 and 33 can be prepared with complete selectivity by applying the appropriate reaction conditions. In aqueous mixtures only the anhydride moiety is transformed to the corresponding imide, whereas the neat reaction condition also enables the transformation of the acetyl moiety to the corresponding imine functionality.

\subsection{The synthesis of tetraalkyl tetraesters of bicyclo[2.2.2] oct-7-ene-2,3,5,6- tetracarboxylic acid}

A fused anhydride ring can serve as a useful synthon for the preparation of the ester derivatives of the corresponding acids. The transformation usually involves the anhydride ring opening with alcohols in the presence of an acidic catalyst. For example, Uno et al. developed a transformation of the dianhydride $\mathbf{6 a}$ into the corresponding tetramethyl tetraester 34a, employing trimethyl orthoacetate as the dehydrating agent and $p$ - $\mathrm{TsOH}$ as an acidic catalyst (Scheme 13). ${ }^{25}$

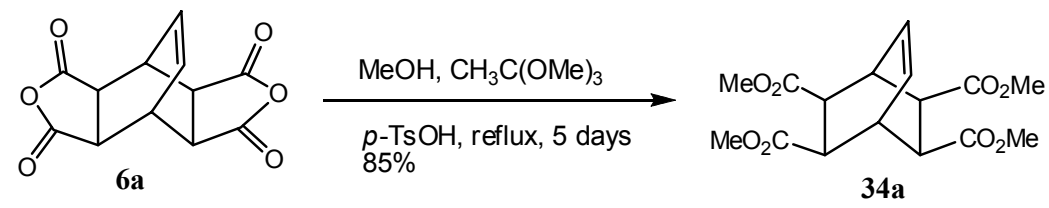

Scheme 13. Transformation of 6 a into tetramethyl tetraester derivative 34a.

For the preparation of the ethyl tetraester derivative $\mathbf{3 4 b}$ similar reaction conditions were applied. The only difference was that toluene was used to raise the temperature of the refluxing reaction mixture and molecular sieves $(4 \AA)$ were employed to remove the water from the reaction mixture (Scheme 14).

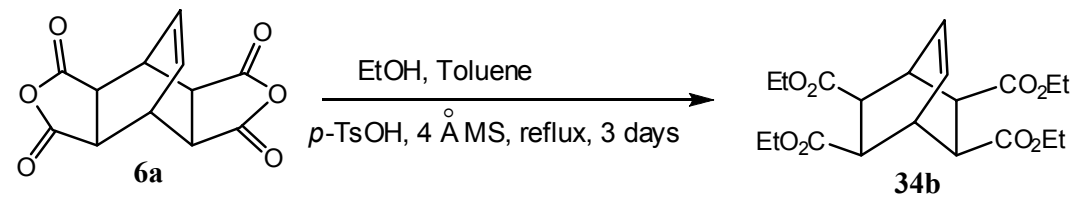

Scheme 14. Transformation of $6 \mathbf{a}$ into tetraethyl tetraester $34 \mathrm{~b}$ derivative. 
The above reaction conditions can also be applied to the synthesis of the tetrabutyl tetraester derivative. $^{26}$

\section{Other Transformations of Bicyclo[2.2.2]oct-7-ene-2,3,5,6-tetracarboxylic Acid Derivatives}

There were some reports of further transformations of the above tetraesters. ${ }^{27}$ Base-catalyzed isomerisation of 34a yielded the all-trans $\mathbf{3 5}$ and the trans-cis-trans derivative $\mathbf{3 6}$ in the ratio 4:1 (35 obtained in an 83\% total yield). ${ }^{25}$ Reduction of the main product 35 with $\mathrm{LiAlH}_{4}$ proceeded smoothly to the corresponding tetraalcohol 37, which was further transformed to the corresponding chloro derivative 38. The latter gives, after an elimination reaction with $\mathrm{KOH}$, a pentaene derivative 39 (Scheme 15). ${ }^{25,26}$

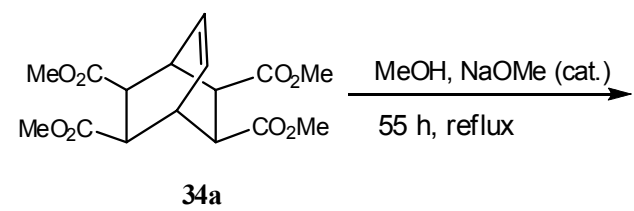

$34 a$

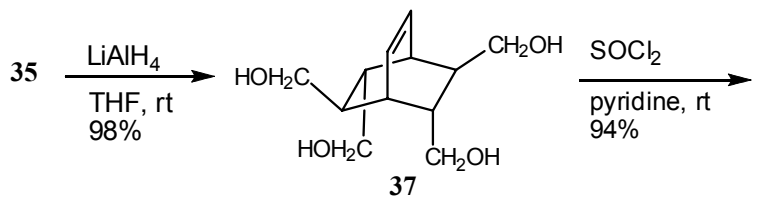

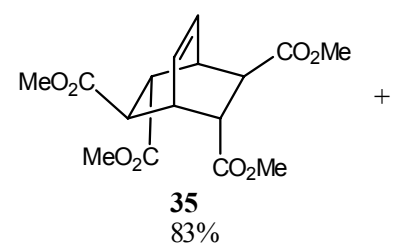

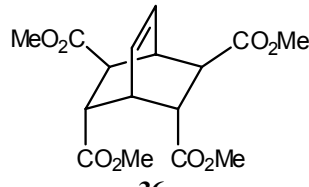

36

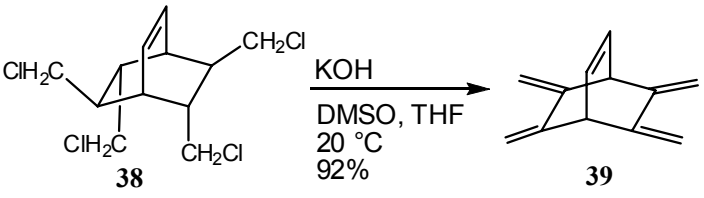

Scheme 15. Isomerisation of bicyclo[2.2.2] oct-7-ene-tetracarboxylic acid tetramethyl ester and its further transformations.

Another interesting reaction of the fused bicyclo[2.2.2] octene ring system is a reduction of the bis(succinimide) derivative 30 with $\mathrm{LiAlH}_{4}$, which gives product 40, containing fused pyrrolidine rings (Scheme 16). ${ }^{23}$ The amine $\mathbf{4 0}$ can be further quaternized with ethyl bromide.
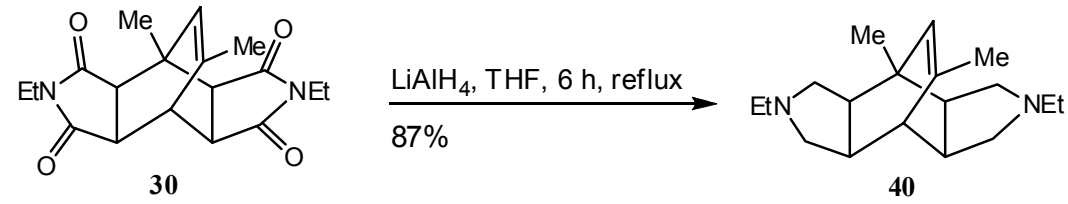

40

Scheme 16. Reduction of disuccinimide derivative of bicyclo[2.2.2] octene $\mathbf{3 0}$ with $\mathrm{LiAlH}_{4}$. 


\section{Transformations of the Bicyclo[2.2.2] octene $C=C$ Double Bond}

There have been relatively few reports of double-bond transformation in the bicyclo[2.2.2]octene systems. One very interesting example of double-bond functionalization is the hydroboration of 38, yielding 41 (Scheme 17), as reported by Vogel et al. ${ }^{28}$
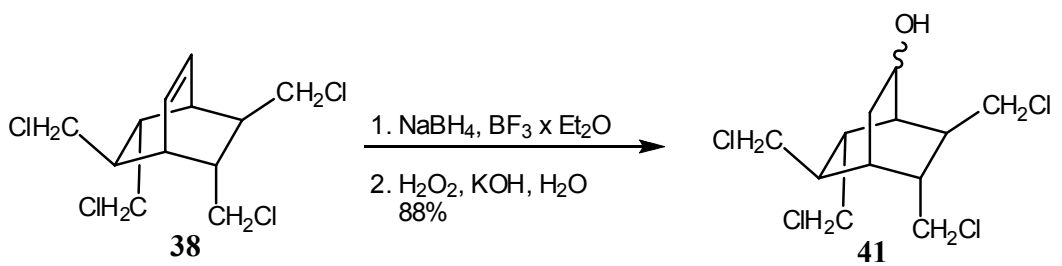

Scheme 17. Hydroboration of 38 to the corresponding alchohol 41.

The alcohol derivative $\mathbf{4 1}$ was oxidized to a ketone, which was further subjected to various rearrangement conditions (Beckmann, Baeyer-Villiger), yielding the corresponding amide and ester. ${ }^{29}$ Compound 38 was also subjected to an epoxidation reaction with $m$-CPBA in EtOAc and the racemic epoxide was obtained in a $90 \%$ yield. ${ }^{30}$ The double bond in the compound 34 a was proven to be extremely unreactive towards epoxidation conditions as the only successful condition applied to this transformation was the HOF $\mathrm{x}$ MeCN complex (dimethyldioxirane and $m$-CPBA failed) yielding 42 (Scheme 18). ${ }^{31}$

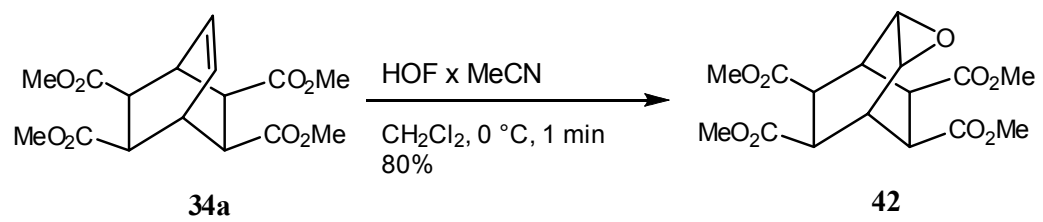

Scheme 18. Successful epoxidation of 34a to the corresponding epoxide $\mathbf{4 2}$.

It is worth noting that the olefinic bond in dianhydride 6a was unreactive, even to this extremely strong electrophilic reagent.

Two very useful oxidation transformations were applied for the preparation of the compounds used in a stereochemical study of substituted cyclohexanes. The first one was an oxidation of 6a to cyclohexane-1,2,3,4,5,6-hexacarboxylic acid $\mathbf{4 3}$ (Scheme 19). The second was a successful ozonation of 34a (and some of its isomers) followed by an oxidative work-up with hydrogen peroxide and diazomethane, as the esterification reagent, yielding different peresterified stereoisomers of $\mathbf{4 3} .^{32}$ 


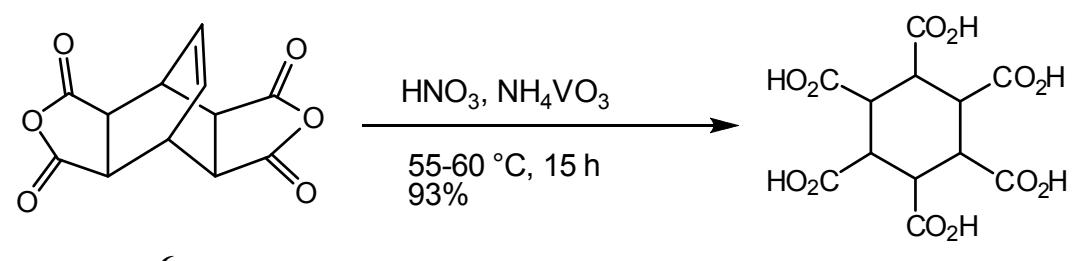

6a

43

Scheme 19. Oxidation of 6a into cyclohexane-1,2,3,4,5,6-hexacarboxylic acid $\mathbf{4 3}$.

The classical double-bond hydrogenation of compound 44 (as a mixture of different stereoisomers) leading to $\mathbf{4 5}$ was reported by Vogel et al. (Scheme 20). ${ }^{27 a}$
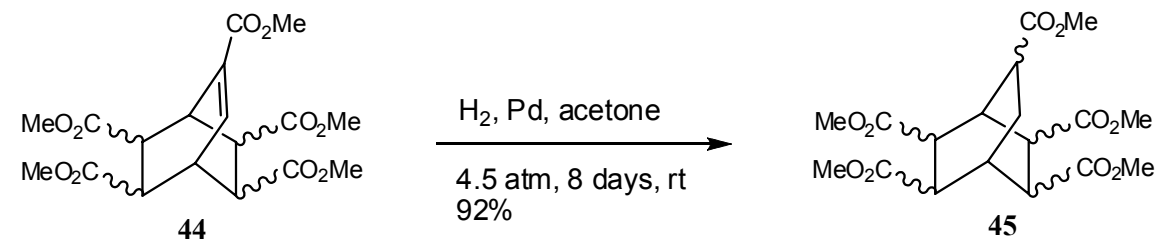

Scheme 20. Reduction of $\mathbf{4 4}$ under classical hydrogenation conditions.

Frejd et al. applied biotransformation conditions to obtain enantiomerically pure 46, which was afterwards reduced to $\mathbf{4 7}$ under standard hydrogenation conditions with the complete retention of stereoselectivity (Scheme 21). ${ }^{33}$

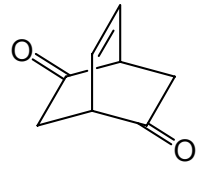

$(+)-46$

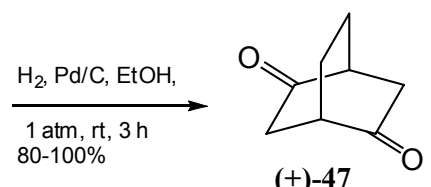

$(+)-47$

Scheme 21. Hydrogenation of the ketone 46.

In our ongoing cooperations with other research groups our substrates were also successfully further transformed under hydrogenation conditions. It was possible to apply $\mathrm{Rh}$ ligands, immobilized on layered double-hydroxide (LDH) supports, for the hydrogenation of bis(succinimide) derivatives of bicyclo[2.2.2]octene. ${ }^{16 \mathrm{a}}$ The supported $\mathrm{Rh}$ catalysts were prepared via ion-exchange ligand immobilization on $\mathrm{LDH} 1\left(\mathrm{Zn}_{3} \mathrm{AlCl}\right)$ and $\mathrm{LDH} 2\left(\mathrm{Co}_{2} \mathrm{FeCO}_{3}\right)$. As the metal ligands, anionic analogues of triphenyphosphane (TPPTS = trisodium salt of 3,3',3''-phosphanetriyl benzenesulfonic acid and TPPTC $=$ trilithium salt of 3,3',3''phosphanetriyl benzencearboxylic acid) were chosen. The catalyst structures and their chemical composition were confirmed by XRD analysis and XPS spectroscopy. As starting materials the compounds $22 \mathbf{c}-\mathbf{f}$ were chosen, which differ only in their substituent at both succinimide 
nitrogens. It was shown that these highly sterically constrained systems are very resistant toward hydrogenation. The activity of both catalytic systems and their selectivity (48 vs. 49) is also strongly dependent on the steric hindrances of the R groups (Scheme 22, Table 8).

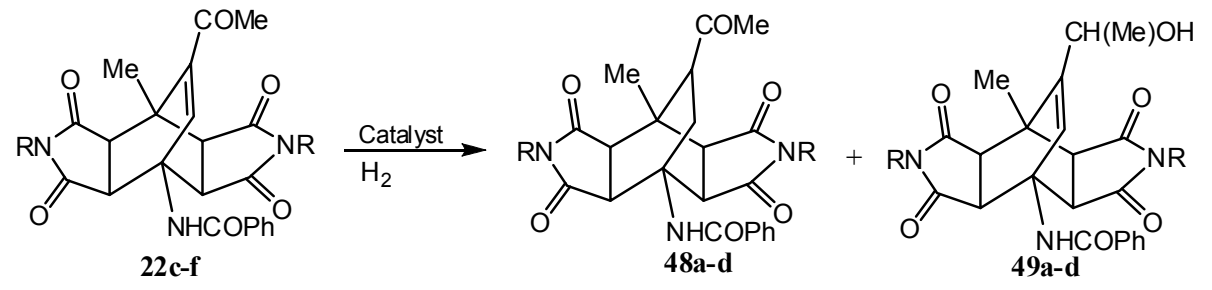

Scheme 22. Hydrogenation of 22 with LDH-immobilized Rh catalysts.

Table 8

\begin{tabular}{ccccccc}
\hline Entry & Cat. & $\mathbf{2 2}$ & $\mathrm{H}_{2}(\mathrm{~atm})$ & $\mathrm{T}\left({ }^{\circ} \mathrm{C}\right)$ & Conversion $(\%)$ & $\begin{array}{c}\text { Selectivity } \\
\mathbf{4 8 : 4 9}\end{array}$ \\
\hline 1 & $\mathrm{~A}$ & $\mathbf{2 2 c}(\mathrm{R}=\mathrm{H})$ & 20 & 80 & 46 & 55 \\
2 & $\mathrm{~A}$ & $\mathbf{2 2 c}(\mathrm{R}=\mathrm{H})$ & 40 & 80 & 83 & 67 \\
3 & $\mathrm{~A}$ & $\mathbf{2 2 d}(\mathrm{R}=\mathrm{Me})$ & 40 & 80 & 55 & 63 \\
4 & $\mathrm{~A}$ & $\mathbf{2 2 e}(\mathrm{R}=\mathrm{Et})$ & 40 & 80 & 45 & 54 \\
5 & $\mathrm{~A}$ & $\mathbf{2 2 e}(\mathrm{R}=\mathrm{Et})$ & 40 & 50 & 22 & 58 \\
6 & $\mathrm{~A}$ & $\mathbf{2 2 f}(\mathrm{R}=\mathrm{Ph})$ & 40 & 80 & 26 & 53 \\
7 & $\mathrm{~B}$ & $\mathbf{2 2 c}(\mathrm{R}=\mathrm{H})$ & 40 & 80 & 46 & 44 \\
8 & $\mathrm{~B}$ & $\mathbf{2 2 d}(\mathrm{R}=\mathrm{Me})$ & 40 & 80 & 27 & 42 \\
9 & $\mathrm{C}$ & $\mathbf{2 2 c}(\mathrm{R}=\mathrm{H})$ & 40 & 80 & 62 & 48 \\
10 & $\mathrm{C}$ & $\mathbf{2 2 d}(\mathrm{R}=\mathrm{Me})$ & 40 & 80 & 44 & 47 \\
\hline
\end{tabular}

${ }^{a}$ Conditions: Substrate 22 (30 mg), catalyst $(30 \mathrm{mg})$, EtOAc $(8 \mathrm{~mL}), 24 \mathrm{~h} .{ }^{\mathrm{b}}$ Catalysts: A, Rh/TPPTS/LDH1; B, Rh/m-TPPTC/LDH1; C, Rh/TPPTS/LDH2. ${ }^{c}$ Determined by HPLC and NMR analysis.

Recently, we have also investigated the possibility of the $\mathrm{C}=\mathrm{C}$ double-bond hydrogenolysis of the substrates 22. Two catalytic systems were tested for this purpose: (a) platinum (Pt) colloids modified by the chiral ligand synphos and subsequently embedded in silica to form a heterogeneous catalytic system ${ }^{34}$ and (b) $\mathrm{Fe}_{3} \mathrm{O}_{4}$ colloids modified by the chiral ligand cinchonidine and also embedded in silica. ${ }^{35}$ No simple $\mathrm{C}=\mathrm{C}$ or $\mathrm{C}=\mathrm{O}$ double-bond hydrogenation products (48 or 49) were obtained, but complex mixtures of interesting products were formed, with different compounds $(\mathbf{5 0}, \mathbf{5 1}$ or $\mathbf{5 2}$, Scheme 23) being predominant in each case. 

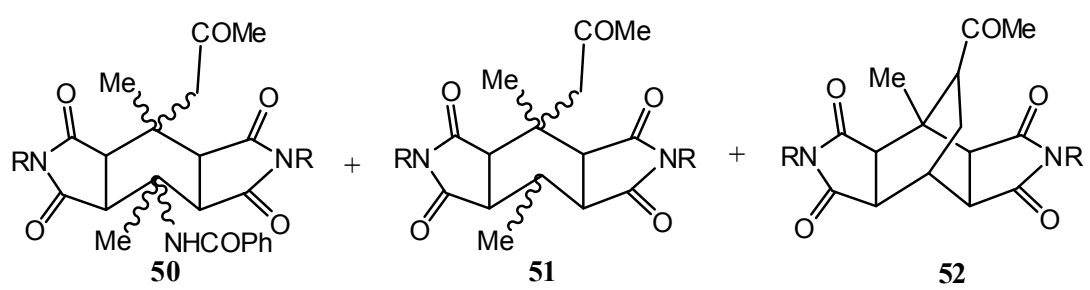

Scheme 23. Hydrogenolysis products of 22 with modified $\mathrm{Pt}$ or $\mathrm{Fe}_{3} \mathrm{O}_{4}$ colloids as catalyst.

It is evident that the ratio of different hydrogenolysis products depends to a large extent on the applied catalytic system. Though no enantioselectivity was observed in these reactions, we believe that the scope of these methodologies will receive further attention in the near future.

\section{Conclusions}

In this account we have summarized our results in the field of bicyclo[2.2.2]octene synthesis along with the selected work of some other research groups. The above discussion proves that the representatives of bicyclo[2.2.2] octene derivatives can be very efficiently synthesized from $2 \mathrm{H}$-pyran-2-one derivatives using the double Diels-Alder reaction of maleic anhydride or substituted maleimides. Bicyclo[2.2.2]oct-7-ene-2exo,3exo,5exo,6exo-tetracarboxylic acid 2,3:5,6-dianhydrides as a starting material enable the synthesis of a wider variety of new bis(succinimide) derivatives through reactions with nitrogen nucleophiles (amines, hydrazines) in high yields. The use of water or neat reaction conditions with the assistance of microwave irradiation renders these syntheses environmentally benign and user friendly. Fused dianhydrides can be further transformed to the corresponding acids and their derivatives, which could serve as useful intermediates for the preparation of a variety of interesting products. Finally, reactions of the $\mathrm{C}=\mathrm{C}$ double bonds of bicyclo[2.2.2] octenes have shown their potential for the synthesis of new products, valuable for organic synthesis, that are otherwise not easily obtained. It is also important to mention that the reported conversions bring about an additional insight into the chemistry of heterocyclic dehydro- $\alpha$-amino acid derivatives. ${ }^{36}$

\section{Acknowledgements}

We thank the Ministry of Higher Education, Science and Technology of the Republic of Slovenia and the Slovenian Research Agency for their financial support (P1-0230-0103). 


\section{References and Notes}

1. Asaoka, M.; Ishibashi, K.; Yanagida, N.; Takei, H. Tetrahedron Lett. 1983, 24, 5127.

2. Magnus, P.; Gazzard, L.; Hobson, L.; Payne, A. H.; Rainey, T. J.; Westlund, N.; Lynch, V. Tetrahedron 2002, 58, 3423.

3. Deutsch, H. M.; Gelbaum, L. T.; McLaughlin, M.; Fleischmann, T. J.; Earnhart, L. L.; Haugwitz, R. D.; Zalkow, L. H. J. Med. Chem. 1986, 29, 2164.

4. (a) Diels, O.; Alder, K. Liebigs Ann. Chem. 1931, 490, 257. (b) Afarinkia, K.; Vinader, V.; Nelson, T. D.; Posner, G. H. Tetrahedron 1992, 48, 9111. (c) Woodard, B. T.; Posner, G. H. In Advances in Cycloaddition; Harmata, M., Ed.; JAI Press Inc.: Greenwich, 1999; Vol. 5, pp 47-83. (d) Komatsu, K.; Nishinaga, T. Synlett 2005, 187.

5. The names of the compounds $\mathbf{6}$, as used in this review, are in accordance with the naming system of the Beilstein database (with type I described using the stereodescriptor exo). Nevertheless, the sterochemistry of such a type of products was specified by many authors in accordance with the endo rule, as described by Alder and Stein, as all-endo or endo, endo products: (a) Alder, K.; Stein, G. Angew. Chem. 1937, 50, 510. (b) Miller, B. Advanced Organic Chemistry: Reactions and Mechanisms; Prentice-Hall, Inc.: Upper Saddle River, New Jersey, 1998; pp 51-82.

6. (a) Effenberger, F.; Ziegler, T. Chem. Ber. 1987, 120, 1339. (b) Gapeeva, M. V.; Stepanjac, U.; Shusherina, N. P.; Knirel', Ju. A.; Levina, R. Ja. Zh. Org. Khim. 1971, 7, 2426; Chem. Abstr. 1972, 76, 59494. (c) Shusherina, N. P. Russ. Chem. Rev. 1974, 43, 851 (Shusherina, N. P. Usp. Khim. 1974, 43, 1771; Chem. Abstr. 1975, 82, 43205).

7. Allen, C. F. H.; Van Allan, J. J. Am. Chem. Soc. 1942, 64, 1260.

8. O’Donovan, A. R. M.; Shepherd, M. K. Tetrahedron Lett. 1994, 35, 4425.

9. Koreeda, M.; Ciufolini, M. A. J. Am. Chem. Soc. 1982, 104, 2308.

10. Gupta, A. K.; Ila, H.; Junjappa, H. Tetrahedron 1989, 45, 1509.

11. Kende, A. S.; Lan, J.; Arad, D. Tetrahedron Lett. 2002, 43, 5237.

12. For the preparation of 3-acylamino substituted $2 H$-pyran-2-ones and fused pyran-2-ones, see: (a) Kočevar, M.; Polanc, S.; Tišler, M.; Verček, B. Synth. Commun. 1989, 19, 1713. (b) Kepe, V.; Kočevar, M.; Polanc, S.; Verček, B.; Tišler, M. Tetrahedron 1990, 46, 2081. (c) Kočevar, M.; Polanc, S.; Verček, B.; Tišler, M. Liebigs Ann. Chem. 1990, 501. (d) Kepe, V.; Kočevar, M.; Petrič, A.; Polanc, S.; Verček, B. Heterocycles 1992, 33, 843. (e) Kepe, V.; Kočevar, M., Polanc, S. Heterocycles 1995, 41, 1299. (f) Kepe, V.; Kočevar, M.; Polanc, S. J. Heterocycl. Chem. 1996, 33, 1707. (g) Kepe, V.; Polanc, S., Kočevar, M. Heterocycles 1998, 48, 671. (h) Požgan, F.; Kranjc, K.; Kepe, V.; Polanc, S.; Kočevar, M. ARKIVOC 2007, (vii), 97.

13. Kranjc, K.; Leban, I.; Polanc, S.; Kočevar, M. Heterocycles 2002, 58, 183.

14. Shimo, T.; Matsushita, M; Omar, H. I.; Somekawa, K. Tetrahedron 2005, 61, 8059.

15. Kranjc, K.; Polanc, S.; Kočevar, M. Org. Lett. 2003, 5, 2833. 
16. (a) Kranjc, K.; Kočevar, M.; Iosif, F.; Coman, S. M.; Parvulescu, V. I.; Genin, E.; Genêt, J.P.; Michelet, V. Synlett 2006, 1075. (b) Kranjc, K.; Kočevar, M. Heterocycles 2007, 73, 481.

17. Kranjc, K.; Kočevar, M. Bull. Chem. Soc. Jpn. 2007, 80, 2001.

18. Kranjc, K.; Kočevar, M. Collect. Czech. Chem. Commun. 2006, 71, 667.

19. (a) Ogliaruso, M. A.; Wolfe, J. F. In Synthesis of Carboxylic Acids, Esters and Their Derivatives; Wiley: New York, 1991, pp 198-217. (b) The chemistry of amides; Zabicky, J., Ed.; Interscience: London, 1970.

20. Verma, S. M.; Maurya, H. Indian J. Chem. 1985, $24 B, 447$.

21. (a) Martelanc, M.; Kranjc, K.; Polanc, S.; Kočevar, M. Green Chem. 2005, 7, 737. (b) Hren, J.; Kranjc, K.; Polanc, S.; Kočevar, M. Heterocycles 2007, 72, 399.

22. Liu, Z.-M.; Liu, Y.; Zheng, S.-R.; Yu, Z.-Q.; Pan, M.; Su, C.-Y. Inorg. Chem. 2007, 46, 5814.

23. Cantín, A.; Corma, A.; Diaz-Cabanas, M. J.; Jordá, J. L.; Moliner, M. J. Am. Chem. Soc. 2006, 128, 4216.

24. Hren, J.; Kranjc, K.; Polanc, S.; Kočevar, M. Synthesis 2008, 452.

25. Uno, H.; Watanabe, H.; Yamashita, Y.; Ono, N. Org. Biomol. Chem. 2005, 3, 448.

26. Ten Hoeve, W.; Huisman, B.-H. PCT Int. Appl. WO 2004 083160, 2004, 21pp.; Chem. Abstr. 2004, 141, 313919s.

27. (a) Burnier, G.; Schwager, L.; Vogel, P. Helv. Chim. Acta 1986, 69, 1310. (b) Demarchi, B.; Vogel, P. Helv. Chim. Acta 1988, 71, 1249.

28. Gabioud, R.; Vogel, P. Helv. Chim. Acta 1983, 66, 1143.

29. Demarchi, B.; Vogel, P. Tetrahedron Lett. 1987, 28, 2239.

30. Gabioud, R.; Vogel, P. Tetrahedron 1980, 36, 149.

31. Golan, E.; Hagooly, A.; Rozen, S. Tetrahedron Lett. 2004, 45, 3397.

32. Farina, M.; Grassi, M.; Di Silvestro, G. J. Am. Chem. Soc. 1985, 107, 5100.

33. Friberg, A.; Johanson, T.; Franzén, J.; Gorwa-Grauslund, M. F.; Frejd, T. Org. Biomol. Chem. 2006, 4, 2304.

34. Neaţu, F.; Kraynov, A.; Pârvulescu, V. I.; Kranjc, K.; Kočevar, M.; Ratovelomanana-Vidal; V.; Richards, R. Nanotechnology 2008, 19, art. no. 225702.

35. Neațu, F.; Kraynov, A.; D'Souza, L.; Pârvulescu, V. I.; Kranjc, K.; Kočevar, M.; Kuncser, V.; Richards, R. Appl. Catal. A: General 2008, 346, 28.

36. For selected recent examples of different types of heterocyclic dehydroamino acid derivatives and their transformations, see also: (a) Kočevar, M.; Polanc, S.; Tišler, M.; Verček, B. Heterocycles 1990, 30, 227. (b) Mušič, I.; Golobič, A.; Verček, B. Heterocycles 1998, 48, 353. (c) Polak, M.; Verček, B. Synth. Commun. 2000, 30, 2863. (d) Trček, T.; Meden, A.; Verček, B. Synlett 2000, 1458. (e) Vraničar, L.; Meden, A.; Polanc, S.; Kočevar, M. J. Chem. Soc., Perkin Trans. 1 2002, 675. (f) Ferreira, P. M. T.; Maia, H. L. S.; Monteiro, L. S. Eur. J. Org. Chem. 2003, 2635. (g) Trcek, T.; Vercek, B. ARKIVOC 2003, (xiv), 246. (h) Trček T.: Verček, B. ARKIVOC 2005, (xiv), 96. (i) Trček, T.; Verček, B. Acta 
Chim. Slov. 2005, 52, 171. (j) Trček, T.; Verček, B. Synthesis 2006, 3437. (k) Požgan, F.; Krejan, M.; Polanc, S.; Kočevar, M. Heterocycles 2006, 69, 123. (1) Požgan, F.; Polanc, S.; Kočevar, M. Tetrahedron 2006, 62, 9718. (m) Požgan, F.; Kafka, S.; Polanc, S.; Kočevar, M. Heterocycles 2006, 70, 235. (n) Kranjc, K.; Kočevar, M. Tetrahedron 2008, 64, 45. (o) Čuček, K.; Verček, B. Synthesis 2008, 1741. (p) Požgan, F.; Kočevar, M. Heterocycles 2009, 77, Prepress REV-08-SR(F)5, 25 September, 2008, http://data.heterocycles.jp/; and references cited therein.

\section{Authors' biographies}

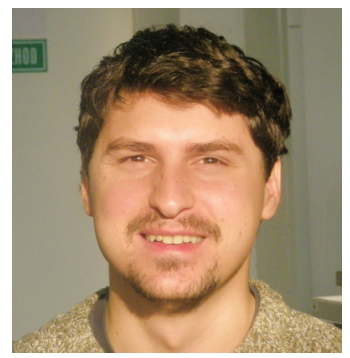

Jure Hren was born in Celje, Slovenia, in 1981 and studied chemistry at the Faculty of Chemistry and Chemical Technology, University of Ljubljana, from 2000 to 2005. He obtained his Diploma in 2005 under the supervision of Professor Boris Šket. He has been working with his postgraduate studies under the supervision of Professor Marijan Kočevar at the Faculty of Chemistry and Chemical Technology, University of Ljubljana, since October 2006. He is currently finishing his $\mathrm{Ph}$. D. thesis on the synthesis of unsaturated amino acid derivatives and synthesis and transformations of bicyclo[2.2.2] octene derivatives. His research interests include synthetic organic chemistry, Diels-Alder reactions and transition metal catalysis.

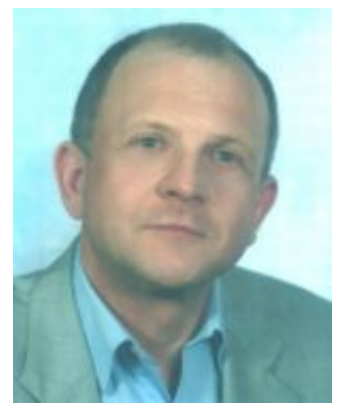

Slovenko Polanc obtained Ph.D. degree in 1975 from the University of Ljubljana (supervisor: Professor Branko Stanovnik). He joined a group of Professor Peter A. Jacobi at the Wesleyan University, Middletown, Connecticut, USA, as a Research Associate in 1980, working one year on the total synthesis of saxitoxin. He had been a Visiting Scientist with Professor Heinz G. Viehe at the University of Louvain, Louvain-la-Neuve, Belgium, for six months during 1986-1987. His research interests include the synthesis of biologically active nitrogen- 
containing organic compounds, a development of new reagents and their application in organic chemistry, and new synthetic methods in heterocyclic chemistry. He is Professor of Organic Chemistry at the Faculty of Chemistry and Chemical Technology, University of Ljubljana, Slovenia.

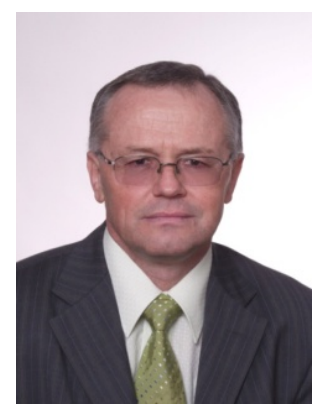

Marijan Kočevar was born in Slovenia in 1949. He graduated in chemistry from the University of Ljubljana in 1974, and finished his M.Sc. (1978) and Ph.D. (1982) degrees under the supervision of Professor Miha Tišler. He became an Assistant Professor in 1983, Associate Professor in 1988, and Professor in 1997 at the University of Ljubljana, where he is currently Professor of Organic Chemistry at the Faculty of Chemistry and Chemical Technology. His research interests include heterocyclic chemistry, amino acids, especially unsaturated amino acids, oxidations and reductions, cycloaddition reactions, structural investigations in solution, catalysis, green chemistry, and high-pressure chemistry. In 1999 he was awarded the Hanus Medal by the Czech Chemical Society in recognition of his contribution to the field of chemistry. 